\title{
Study of socio - emotional problems of academically backward students of Punjab Govt. Sen. Sec. Schools
}

\author{
Vandana Kanwar, Asha Chawla and Shiksha Rani
}

Received: 26.05.2018; Revised: 27.10.2018; Accepted: 10.11.2018

See end of the paper for authors' affiliations

Vandana Kanwar

Department of Human

Development and Family Studies,

College of Home Science, Punjab

Agricultural University, Ludhiana

(Punjab) India

Email : knwarvandana@pau.edu
ABSTRACT : The study investigated the socio - emotional problems of academically backward students studying in government senior secondary schools in rural areas of Ludhiana district of Punjab. The sample comprised of total 150 academically backward students. Purposive sampling technique was used for the sample selection. Socio-emotional problems scale (AICRP - CD) was used to assess the socio emotional problems of children. The results revealed that the majority of the academically backward children were unhappy, worried, ill tempered, avoided interactions with others, liked to be alone, short tempered, jealous of others, stubborn, quarreled with siblings and showed nervousness etc.

KEY WORDS: Social -emotional problems, Academic backwardness, Students, Govt. schools

- HOW TO CITE THIS PAPER : Kanwar, Vandana, Chawla, Asha and Rani, Shiksha (2018). Study of socio - emotional problems of academically backward students of Punjab Govt. Sen. Sec. Schools. Asian J. Home Sci., 13 (2) : 569-575, DOI: 10.15740/HAS/AJHS/13.2/569-575. Copyright@ 2018: Hind AgriHorticultural Society. 